\title{
Orphanin FQ/ nociceptin interacts with the basolateral amygdala noradrenergic system in memory consolidation
}

\author{
Benno Roozendaal, ${ }^{1,5}$ Ray Lengvilas, ${ }^{1}$ James L. McGaugh, ${ }^{1}$ Olivier Civelli, ${ }^{2,3}$ \\ and Rainer K. Reinscheid ${ }^{2,4}$ \\ ${ }^{1}$ Center for the Neurobiology of Learning and Memory and Department of Neurobiology and Behavior, University of California, \\ Irvine, California 92697-3800, USA; ${ }^{2}$ Department of Pharmacology, College of Medicine, University of California, Irvine, \\ California 92697-4625, USA; ${ }^{3}$ Department of Developmental and Cell Biology, University of California, Irvine, California \\ 92697-2300, USA; ${ }^{4}$ Program in Pharmaceutical Sciences, University of California, Irvine, California 92697-3950, USA
}

\begin{abstract}
Extensive evidence indicates that the basolateral complex of the amygdala (BLA) mediates hormonal and neurotransmitter effects on the consolidation of emotionally influenced memory and that such modulatory influences involve noradrenergic activation of the BLA. As the BLA also expresses a high density of receptors for orphanin $\mathrm{FQ} /$ nociceptin (OFQ/N), an opioid-like peptide with anxiolytic and amnestic properties, the present experiments investigated whether the BLA is involved in mediating OFQ/N effects on memory consolidation and whether such effects require noradrenergic activity. OFQ/N (0.01-100 pmol in $0.2 \mu \mathrm{L})$ administered bilaterally into the BLA of male Sprague-Dawley rats immediately after aversively motivated inhibitory avoidance training induced dose-dependent impairment on a 48-h retention trial. The $\boldsymbol{\beta}_{1}$-adrenoceptor antagonist atenolol $(2.0 \mathrm{nmol})$ administered concurrently into the BLA potentiated the dose-response effects of $\mathrm{OFQ} / \mathrm{N}$. In contrast, immediate post-training infusions of the peptidergic OFQ/ $\mathrm{N}$ receptor antagonist [Nphe']nociceptin(1-13) $\mathrm{NH}_{2}(1-100$ pmol in 0.2 $\mu \mathrm{L}$ ) into the BLA enhanced 48-h retention of inhibitory avoidance training, an effect that was blocked by coadministration of atenolol. Delayed infusions of OFQ/N or [Nphe']nociceptin(1-13) $\mathrm{NH}_{2}$ into the BLA administered either 6 or $3 \mathrm{~h}$ after training, respectively, or immediate post-training infusions of OFQ/N into the adjacent central amygdala did not significantly alter retention performance. These findings indicate that endogenously released $\mathrm{OFQ} / \mathrm{N}$ interacts with noradrenergic activity within the BLA in modulating memory consolidation.
\end{abstract}

Orphanin $\mathrm{FQ} /$ nociceptin $(\mathrm{OFQ} / \mathrm{N})$ is a heptadecapeptide that is implicated in a variety of physiological functions, including stress vulnerability, anxiety, locomotion, and nociception (Meunier et al. 1995; Reinscheid et al. 1995; Calo et al. 2000). Although $\mathrm{OFQ} / \mathrm{N}$ is structurally and functionally related to opioid peptides, it does not cross-activate the classical opioid receptors, but binds with high affinity to the opioid receptor-like 1 receptor $\left[\mathrm{ORL}_{1}\right.$; now known as the nociceptin/orphanin FQ peptide (NOP) receptor (Foord et al. 2005)] in the brain. As NOP receptors are highly expressed in the hippocampus and amygdala (Bunzow et al. 1994; Fukuda et al. 1994; Lachowicz et al. 1996; Neal Jr. et al. 1999a; Florin et al. 2000; Bridge et al. 2003), there is growing interest in the function of the OFQ/N-NOP system in these brain regions in learning and memory (Noda et al. 2000; Mamiya et al. 2003). Previous studies reported that $\mathrm{OFQ} / \mathrm{N}$ administered either peripherally or into the ventricular system shortly before training impairs performance on a variety of learning tasks (Hiramatsu and Inoue 1999; Higgins et al. 2002), and that direct infusions of $\mathrm{OFQ} / \mathrm{N}$ into the hippocampus impair, or at lower doses enhance, acquisition and retention on a water-maze spatial task (Sandin et al. 1997, 2004; Redrobe et al. 2000). Furthermore, mice that lack OFQ/N or the NOP receptor show improved learning and memory abilities (Manabe et al. 1998; Higgins et al. 2002) and larger long-term potentiation in the CA1 region of the hippocampus than control mice (Manabe et al. 1998).

\section{${ }^{5}$ Corresponding author.}

E-mail broozend@uci.edu; fax (949) 824-2952.

Article published online in January 2007. Article and publication date are at http://www.learnmem.org/cgi/doi/10.1101/lm.403607.
Although $\mathrm{OFQ} / \mathrm{N}$ has been reported to reduce excitability of amygdala neurons (Meis and Pape 1998, 2001), studies have not, as yet, investigated whether the amygdala is involved in mediating $\mathrm{OFQ} / \mathrm{N}$ effects on learning and memory. It has long been known that the basolateral complex of the amygdala (BLA; consisting of the lateral, basal, and accessory basal nuclei) is an important brain region involved in mediating drug effects on longterm memory formation (McGaugh 2000). Immediate posttraining infusions of opioids or their antagonists into the BLA as well as drugs affecting a wide variety of other neurotransmitter systems modulate the consolidation of long-term memory (Gallagher and Kapp 1978; Introini-Collison et al. 1989; McGaugh 2004). The BLA is particularly involved in regulating memory consolidation of emotionally arousing experiences, and interactions of neuromodulatory systems with training-induced noradrenergic activity within the BLA may form the basis of this selectivity (McIntyre et al. 2003; McGaugh 2004; Roozendaal et al. 2006). For example, a $\beta$-adrenoceptor antagonist administered either peripherally or selectively into the BLA attenuates the memory-modulatory effects of many drugs (Izquierdo and McGaugh 1985; McGaugh et al. 1988; Introini-Collison et al. 1989; McGaugh 2004). Furthermore, peripheral administration of drugs that enhance memory consolidation, including the opioid receptor antagonist naloxone, increases training-induced release of norepinephrine in the BLA, whereas drugs that impair memory consolidation, including $\beta$-endorphin, are known to decrease amygdala norepinephrine levels (Quirarte et al. 1998; Hatfield et al. 1999). Interestingly, peripheral administration of the nonpeptide competitive NOP receptor antagonist J-113397 tonically increases norepinephrine levels in the amygdala, and this 
increase is strongly suppressed by local infusions of $\mathrm{OFQ} / \mathrm{N}$ into the amygdala (Kawahara et al. 2004).

The present experiments investigated whether the OFQ/NNOP system in the BLA influences memory consolidation and whether these effects depend on interactions with the noradrenergic system. In a first experiment, different doses of OFQ/N were administered into the BLA either alone or together with the $\beta_{1}$ adrenoceptor antagonist atenolol immediately after aversively motivated inhibitory avoidance training. Retention was tested 48 $\mathrm{h}$ after the training trial. A second experiment investigated the effects of intra-BLA infusions of the peptidergic NOP receptor antagonist [ $\mathrm{Nphe}^{1}$ ]nociceptin(1-13) $\mathrm{NH}_{2}$ administered either alone or together with atenolol immediately after inhibitory avoidance training to determine whether $\mathrm{OFQ} / \mathrm{N}$ is endogenously released in the BLA and normally plays a role in memory consolidation. To control for time and site specificity, other groups of rats received intra-BLA infusions of $\mathrm{OFQ} / \mathrm{N}$ or the NOP receptor antagonist 3 or $6 \mathrm{~h}$ after training or immediate post-training infusions of $\mathrm{OFQ} / \mathrm{N}$ into the neighboring central amygdala (CEA).

\section{Results}

\section{Post-training intra-BLA infusions of OFQ/N impair inhibitory avoidance retention performance: Involvement of $\boldsymbol{\beta}$-adrenergic mechanisms}

This experiment investigated whether $\mathrm{OFQ} / \mathrm{N}$ infused into the BLA immediately after inhibitory avoidance training would impair memory consolidation and whether coadministration of a $\beta$-adrenoceptor antagonist would alter the dose-response effects of $\mathrm{OFQ} / \mathrm{N}$. Average step-through latencies for all groups during training, before footshock or drug treatment, were $13.5 \pm 0.6 \mathrm{sec}$ (mean \pm SEM). Two-way ANOVA for training latencies revealed no significant differences between groups (for all comparisons: $P \geq 0.22$ ). Forty-eight-hour retention latencies of rats infused with saline into the BLA immediately after training were significantly longer than their latencies during the training trial $(264.8 \pm 60.9 \mathrm{sec}$; paired $t$-test: $P<0.01)$, indicating that the rats retained memory of the shock experience. As shown in Figure 1A, immediate post-training infusions of $\mathrm{OFQ} / \mathrm{N}$ into the BLA induced dose-dependent retention impairment, and atenolol potentiated the dose-response effects of OFQ/N. A two-way ANOVA for retention latencies revealed no atenolol effect $\left(F_{1,126}=0.08\right.$;
$P=0.77)$, but a significant $\mathrm{OFQ} / \mathrm{N}$ effect $\left(F_{5,126}=2.62 ; P<0.05\right)$ and a significant interaction between both factors $\left(F_{5,126}=5.15\right.$; $P<0.0005)$. OFQ/N induced dose-dependent impairment of retention latencies. Retention latencies of rats given post-training infusions of 1,10 , or $100 \mathrm{pmol}$ of $\mathrm{OFQ} / \mathrm{N}$ were significantly shorter than those of rats given saline ( 1 and 10 pmol: $P<0.01$; 100 pmol: $P<0.05)$. Lower doses of $\mathrm{OFQ} / \mathrm{N}(0.01$ and $0.1 \mathrm{pmol})$ did not significantly impair retention $(P \geq 0.52)$. The specific $\beta_{1^{-}}$ adrenoceptor antagonist atenolol infused into the BLA immediately after inhibitory avoidance training did not impair retention latencies when administered alone $(P=0.49)$, but shifted the dose-response effects of $\mathrm{OFQ} / \mathrm{N}$ to the left. In rats given atenolol, the two lower doses of $\mathrm{OFQ} / \mathrm{N}(0.01$ and $0.1 \mathrm{pmol})$ significantly impaired retention performance (both, $P<0.01$ ), whereas higher doses were ineffective. Retention latencies of rats given either the 0.01- or 0.1-pmol dose of $\mathrm{OFQ} / \mathrm{N}$ into the BLA together with atenolol were significantly shorter compared to those of rats treated with $\mathrm{OFQ} / \mathrm{N}$ alone $(0.01$ pmol: $P<0.05 ; 0.1 \mathrm{pmol}$ : $P<0.01$ ), whereas retention latencies of rats treated with the 10pmol dose of $\mathrm{OFQ} / \mathrm{N}$ and atenolol were significantly longer than those of rats given $\mathrm{OFQ} / \mathrm{N}$ alone $(P<0.01)$.

To examine whether $\mathrm{OFQ} / \mathrm{N}$ induced retention deficits by impairing the consolidation phase of memory processing, other groups of rats received intra-BLA infusions of OFQ/N ( 1 pmol) or saline 3 or $6 \mathrm{~h}$ after training. As shown in Figure 1B, retention latencies of rats given infusions of $\mathrm{OFQ} / \mathrm{N} 3 \mathrm{~h}$ after training were significantly shorter than those of rats administered saline at that time (unpaired $t$-test: $P<0.01$ ). However, retention latencies of rats given infusions of $\mathrm{OFQ} / \mathrm{N} 6 \mathrm{~h}$ after training did not differ significantly from those of saline controls $(P=0.67)$. Additional infusions of $\mathrm{OFQ} / \mathrm{N}$ were made into the neighboring CEA to assess the site-specificity of OFQ/ $\mathrm{N}$ action. Retention latencies of rats receiving intra-CEA infusions of OFQ/N (1 pmol) immediately after training did not differ from those receiving saline into the CEA $(P=0.48)$ (Fig. 1C).

\section{Post-training intra-BLA infusions of the NOP receptor antagonist [Nphe'] nociceptin(1-13) $\mathrm{NH}_{2}$ enhance inhibitory avoidance retention performance: Involvement of $\boldsymbol{\beta}$-adrenergic mechanisms} In this experiment, we examined whether blockade of NOP receptors in the BLA with post-training infusions of the peptidergic
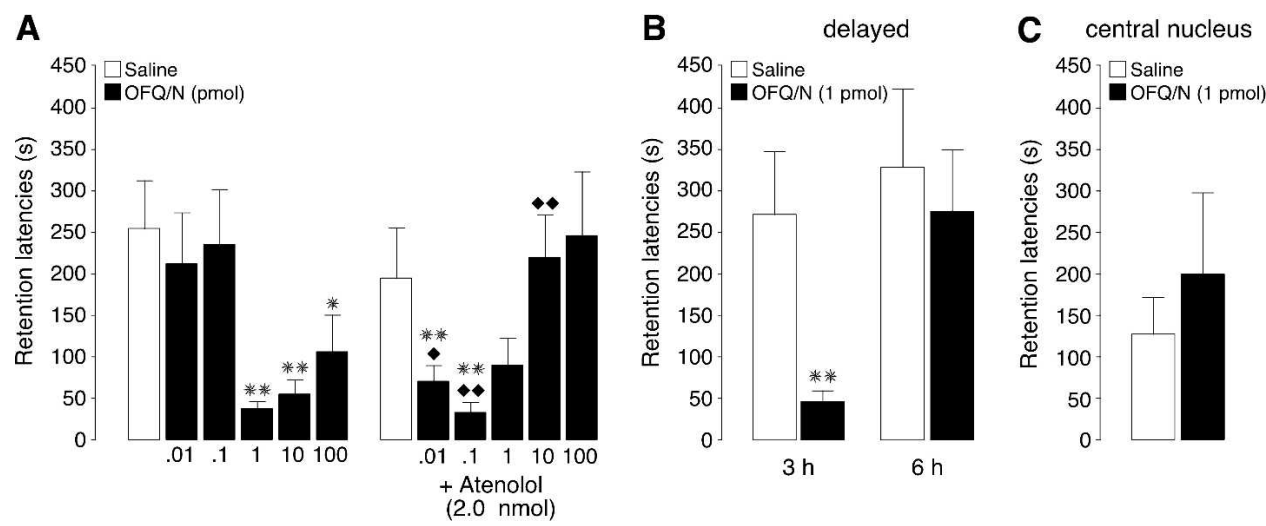

Figure 1. Step-through latencies (mean + SEM) in seconds on a 48-h inhibitory avoidance retention test. ( $A$ ) Immediate post-training infusions of OFQ/N $(0.01,0.1,1,10$, or 100 pmol in $0.2 \mu \mathrm{L})$ into the BLA dose-dependently impaired memory consolidation. The $\beta_{1}$-adrenoceptor antagonist atenolol $(2 \mathrm{nmol})$ administered concurrently into the BLA shifted the dose-response effects of OFQ/N to the left ( $n=9-14$ rats per group). (B) Delayed infusions of OFQ/N (1 pmol in $0.2 \mu \mathrm{L})$ into the BLA administered $3 \mathrm{~h}$ after training impaired memory consolidation, but OFQ/N given $6 \mathrm{~h}$ after training did not impair memory consolidation ( $n=7-10$ rats per group). (C) Immediate post-training infusion of OFQ/N ( $1 \mathrm{pmol}$ in $0.2 \mu \mathrm{L})$ into the CEA did not impair memory consolidation $(n=5-6$ rats per group). (*) $P<0.05$; $(* *) P<0.01$ compared with the corresponding saline group; $(\diamond) P<0.05$; $(\diamond \diamond)$ $P<0.01$ compared with the corresponding OFQ/N group. 
receptor antagonist $\left[\mathrm{Nphe}^{1}\right]$ nociceptin(1-13) $\mathrm{NH}_{2}$ would enhance memory consolidation of inhibitory avoidance training and whether concurrent blockade of $\beta$-adrenoceptors would modify this memory enhancement. A two-way ANOVA for training latencies, before footshock or drug treatment, showed no significant differences between groups (for all comparisons: $P \geq 0.14$ ). Retention latencies of control rats treated with saline were significantly longer than their entrance latencies during training $(P<0.01)$, indicating that this lower-intensity footshock also induced long-term memory. Post-training infusions of [Nphe ${ }^{1}$ nociceptin(1-13) $\mathrm{NH}_{2}$ into the BLA dose-dependently enhanced retention latencies, and atenolol blocked the memory enhancement induced by the NOP receptor antagonist. A twoway ANOVA for retention latencies revealed significant NOP receptor antagonist $\left(F_{3,67}=5.18, P<0.005\right)$ and atenolol effects $\left(F_{1,67}=13.39, P<0.0005\right)$, as well as a significant interaction between both factors $\left(F_{3,67}=5.45, P<0.005\right)$. As shown in Figure $2 \mathrm{~A}$, the 10 -pmol dose of $\left[\mathrm{Nphe}^{1}\right]$ nociceptin(1-13) $\mathrm{NH}_{2}$ significantly enhanced retention latencies $(P<0.01)$, whereas the lower $(1 \mathrm{pmol})$ or higher $(100 \mathrm{pmol})$ doses were ineffective $(P \geq 0.45)$. Atenolol alone did not significantly influence retention latencies as compared to saline-injected rats $(P=0.23)$, but blocked the retention enhancement induced by the NOP receptor antagonist. Rats treated with the 10-pmol dose of [Nphe $\left.{ }^{1}\right]$ nociceptin(113) $\mathrm{NH}_{2}$ together with atenolol had significantly shorter retention latencies than rats treated only with this dose of the NOP receptor antagonist $(P<0.01)$ and did not differ from those of rats treated with either saline or atenolol $(P \geq 0.48)$.

As shown in Figure $2 \mathrm{~B}$, delayed infusions of [Nphe ${ }^{1}$ ]nociceptin(1-13) $\mathrm{NH}_{2}$ (10 pmol) administered $3 \mathrm{~h}$ after inhibitory avoidance training did not significantly enhance retention performance as compared to their saline-treated counterparts (unpaired $t$-test: $P=0.84$ ).

\section{Histology}

Representative photomicrographs of needle tracks terminating within the BLA and CEA are shown in Figure 3, A and B, respectively. Infusion needle tips were found throughout the BLA or CEA, respectively. Only rats with needle tips within the bound-
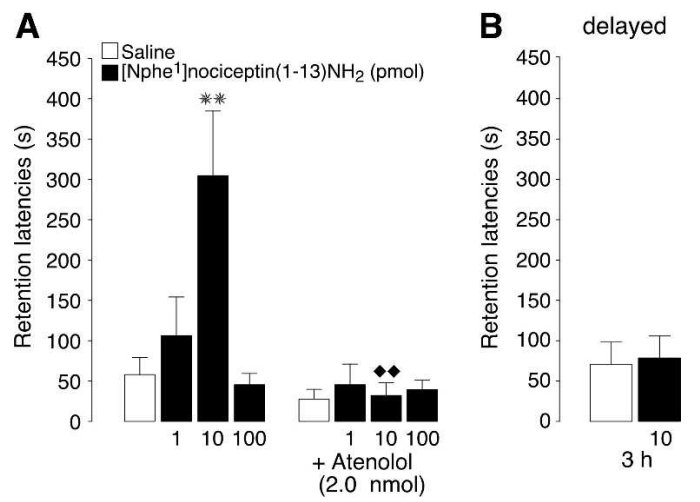

Figure 2. Step-through latencies (mean + SEM) in seconds on a 48-h inhibitory avoidance retention test. $(A)$ Immediate post-training infusions of the NOP receptor antagonist [Nphe ${ }^{1}$ nociceptin(1-13) $\mathrm{NH}_{2}$ $(1,10$, or $100 \mathrm{pmol}$ in $0.2 \mu \mathrm{L})$ dose-dependently enhanced memory consolidation. The $\beta_{1}$-adrenoceptor antagonist atenolol $(2 \mathrm{nmol})$ administered concurrently into the BLA blocked the enhancing effects of [Nphe ${ }^{1}$ ]nociceptin(1-13) $\mathrm{NH}_{2}(n=8-12$ rats per group). (B) Delayed infusions of [Nphe ${ }^{1}$ nociceptin(1-13) $\mathrm{NH}_{2}$ (10 pmol in $\left.0.2 \mu \mathrm{L}\right)$ administered into the BLA $3 \mathrm{~h}$ after training did not enhance memory consolidation ( $n=8-10$ rats per group). (**) $P<0.01$ compared with the corresponding saline group; $(\diamond) P<0.01$ compared with the corresponding [Nphe ${ }^{1}$ ]nociceptin(1-13) $\mathrm{NH}_{2}$ group.

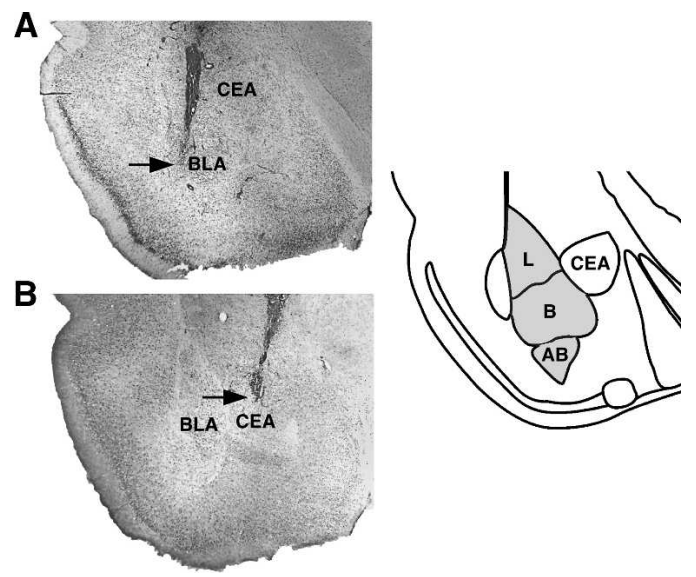

Figure 3. Representative photomicrographs illustrating needle tracks terminating in the BLA $(A)$ and CEA $(B)$. The arrow points to the needle tip. The gray area in the diagram represents the different nuclei of the basolateral complex. (AB) Accessory basal nucleus; (B) basal nucleus; (L) lateral nucleus.

aries of the targeted areas were included in the data analysis. Fifty-eight rats $(\approx 18 \%)$ were excluded from further analysis because of either cannula misplacement or damage to the targeted tissue.

\section{Discussion}

The major findings of these experiments are that post-training infusions of $\mathrm{OFQ} / \mathrm{N}$ into the BLA induced dose- and timedependent impairment of 48-h inhibitory avoidance retention performance and that the $\beta$-adrenoceptor antagonist atenolol coinfused with $\mathrm{OFQ} / \mathrm{N}$ into the BLA potentiated the doseresponse effects of $\mathrm{OFQ} / \mathrm{N}$ on memory impairment. In contrast, post-training blockade of NOP receptors with the receptor antagonist $\left[\mathrm{Nphe}^{1}\right.$ ]nociceptin(1-13) $\mathrm{NH}_{2}$ enhanced inhibitory avoidance retention performance, and atenolol blocked the memory-enhancing effects of $\left[\mathrm{Nphe}^{1}\right]$ nociceptin(1-13) $\mathrm{NH}_{2}$. These findings indicate that the BLA is involved in mediating the impairing effects of endogenous $\mathrm{OFQ} / \mathrm{N}$ on memory of an aversive training experience and that these effects involve interactions with noradrenergic mechanisms within the BLA. Consistent with the findings of many previous pharmacological studies of memory, whereas moderate doses of $\mathrm{OFQ} / \mathrm{N}$ and the NOP receptor antagonist impaired and enhanced retention performance, respectively, lower and higher doses were ineffective. The mechanism underlying this dose-response effect is unknown, but the generality of such a bell-shaped curve across drug systems (e.g., Brioni et al. 1989) strongly suggests that the ineffectiveness of higher doses in the present study is not caused by any specific characteristics of $\mathrm{OFQ} / \mathrm{N}$ or the antagonist, such as desensitization of the NOP receptor or residual agonistic action of the antagonist.

The finding that $\mathrm{OFQ} / \mathrm{N}$ administered into the BLA immediately after inhibitory avoidance training dose-dependently impaired performance on a 48-h retention trial is consistent with that of previous reports indicating that $\mathrm{OFQ} / \mathrm{N}$ administered either peripherally or into the lateral ventricles shortly before training impaired performance on this or other memory tasks (Hiramatsu and Inoue 1999; Higgins et al. 2002). Moreover, the finding that the NOP receptor antagonist enhanced later retention is consistent with that of previous studies examining the effects on memory of mice lacking either $\mathrm{OFQ} / \mathrm{N}$ or the NOP receptor (Manabe et al. 1998; Higgins et al. 2002). However, because most of these previous studies used pre-training adminis- 
tration of $\mathrm{OFQ} / \mathrm{N}$ or genetically altered animals, such findings do not allow any conclusion with respect to whether OFQ/N altered performance by influencing memory consolidation. As $\mathrm{OFQ} / \mathrm{N}$ is known to affect behavior via influences on, for example, stress vulnerability, anxiety, locomotion, and nociception (Mogil and Pasternak 2001), it is possible that OFQ/ $\mathrm{N}$ administered before training may alter acquisition or retention performance by influencing such non-mnemonic processes. Importantly, in the present study, OFQ/N and the NOP receptor antagonist were administered immediately after the footshock training. Thus, the retention performance effects cannot be attributed to such nonspecific effects on acquisition. Moreover, as delayed infusions of these agents administered several hours after training were ineffective, the findings provide evidence that $\mathrm{OFQ} / \mathrm{N}$ and its antagonist modulated time-dependent processes underlying the consolidation of memory of the training. An interesting finding was that $\mathrm{OFQ} / \mathrm{N}$ administered $3 \mathrm{~h}$ after training induced memory impairment, whereas the antagonist administered $3 \mathrm{~h}$ after training was ineffective in enhancing memory consolidation. Such findings would indicate that the BLA is activated for at least $3 \mathrm{~h}$ after aversive stimulation (see Pelletier et al. 2005) and that OFQ/N infused during this period is able to attenuate memory consolidation. Our results also indicate that the memory-modulatory effects of endogenous $\mathrm{OFQ} / \mathrm{N}$ released into the BLA might be significantly shorter since delayed infusions ( $3 \mathrm{~h}$ post-training) of the NOP antagonist to block endogenously released OFQ/N activity were ineffective. Alternatively, these findings may suggest that pharmacological attempts to increase BLA activity are only successful when administered shortly after training coinciding with training-induced neurotransmitter, possibly norepinephrine, release.

$\mathrm{OFQ} / \mathrm{N}$ or its receptor antagonist influenced memory consolidation when administered selectively into the BLA, but not into the adjacent CEA. Such findings are consistent with extensive prior evidence demonstrating memory modulation induced by selective intra-BLA infusions of drugs affecting other neuromodulatory systems (e.g., Tomaz et al. 1993; Parent and McGaugh 1994; Roozendaal and McGaugh 1997; Ma et al. 2005) as well as with evidence that lesions of the BLA, but not the CEA, block the memory-modulatory effects of peripherally administered drugs (Tomaz et al. 1992; Roozendaal and McGaugh 1996). Such a selective involvement of the BLA in memory modulation is also in agreement with both anatomical and functional evidence indicating that neuromodulatory influences within the BLA regulate memory consolidation processes via an extensive network of BLA projections to other brain regions, including the hippocampus and several cortical regions (McGaugh 2004). Both the BLA and the CEA have OFQ/N binding sites and express NOP mRNA, but the density in the BLA is higher (Neal Jr. et al. 1999a). Immunocytochemical studies revealed that the BLA does not appear to have any neurons expressing OFQ/N, but appears to have a moderate density of $\mathrm{OFQ} / \mathrm{N}$-positive fibers and nerve terminals (Neal Jr. et al. 1999b). As the CEA has a high density of OFQ/Nexpressing neurons, the peptide may be axonally transported from the CEA to the BLA. Although the present findings provide strong support for the view that $\mathrm{OFQ} / \mathrm{N}$ is endogenously released in the BLA, it is presently not known whether this release is tonic or triggered by (aversive) training experiences.

$\mathrm{OFQ} / \mathrm{N}$-induced impairment of memory consolidation suggests that $\mathrm{OFQ} / \mathrm{N}$ inhibits BLA neuronal activity. Consistent with this idea, the NOP receptor is a G-protein-coupled membrane receptor that has an inhibitory influence on adenylate cyclase activity and the formation of the second messenger cAMP (Meunier et al. 1995; Reinscheid et al. 1995). Furthermore, an electrophysiogical study using the whole-cell patch-clamp technique reported that $\mathrm{OFQ} / \mathrm{N}$ acts postsynaptically on projection neurons in the lateral division of the BLA (as well as the CEA) to reduce cellular excitability (Meis and Pape 1998). This electrical effect of $\mathrm{OFQ} / \mathrm{N}$ is blocked by administration of a G-protein inhibitor. Blockade of $\beta$-adrenoceptors in the BLA with infusions of atenolol modified the memory-modulatory effects of $\mathrm{OFQ} / \mathrm{N}$ and its receptor antagonist. As norepinephrine stimulates cAMP accumulation via $\beta$-adrenoceptor activation on stimulatory $G$ proteins (Perkins and Moore 1973), it is possible that these two systems interact at the level of adenylate cyclase. There is evidence that the cAMP-PKA signaling pathway is implicated in memory consolidation and mediates the effects of several neuromodulatory systems on memory consolidation (Liang et al. 1995; Ferry et al. 1999; Roozendaal et al. 2002).

In addition to such postsynaptic mechanisms, recent findings suggest that $\mathrm{OFQ} / \mathrm{N}$ may also interact with the noradrenergic system by regulating the release of norepinephrine into the BLA. As indicated, peripheral administration of a NOP receptor antagonist tonically increases norepinephrine levels in the BLA, whereas local administration of OFQ/N strongly suppresses this increase (Kawahara et al. 2004). Furthermore, infusions of OFQ/N alone into the BLA decrease norepinephrine levels. Those findings fit with evidence from our laboratory indicating that other memory-enhancing drugs (e.g., naloxone, epinephrine, picrotoxin, and corticosterone) increase norepinephrine levels in the amygdala, whereas drugs that impair memory consolidation (e.g., $\beta$-endorphin and muscimol) decrease amygdala norepinephrine levels (McGaugh et al. 1996; Quirarte et al. 1998; Williams et al. 1998; Hatfield et al. 1999; McIntyre et al. 2004). It has been suggested that NOP receptors may also be localized presynaptically in the BLA (see Neal Jr. et al. 1999a; Meis and Pape 2001). As training on an emotionally arousing task can induce the local synthesis of norepinephrine in noradrenergic terminals in the BLA (Roozendaal et al. 2006), intra-BLA infusions of $\mathrm{OFQ} / \mathrm{N}$ may regulate the synthesis and/or release of norepinephrine at presynaptic release sites. Additionally, OFQ/N may regulate norepinephrine release indirectly via influences on other neurotransmitters. Meis and Pape (2001) showed that OFQ/N can act at presynaptic sites in the amygdala to regulate the release of GABA and glutamate. As GABA directly reduces the release of norepinephrine in the BLA (Hatfield et al. 1999), such findings open the possibility that $\mathrm{OFQ} / \mathrm{N}$ may also alter norepinephrine levels in the BLA via a modulation of GABAergic mechanisms.

The finding that the $\mathrm{OFQ} / \mathrm{N}-\mathrm{NOP}$ system interacts with noradrenergic mechanisms in the BLA in influencing memory consolidation is consistent with extensive evidence indicating that the memory-modulatory effects of drugs affecting many other neuromodulatory and hormonal systems, including opioid peptides, corticotropin-releasing hormone, dopamine, epinephrine, and glucocorticoids, rely on noradrenergic activation within the BLA or-as assessed in earlier studies-within the amygdaloid complex (Dias et al. 1979; Liang et al. 1986; Introini-Collison et al. 1989; McGaugh et al. 1996; LaLumiere et al. 2004; McGaugh 2004). Such an interaction with the noradrenergic system may have important consequences for the role of $\mathrm{OFQ} / \mathrm{N}$ in regulating memory consolidation. In a recent study investigating the effects of adrenocortical stress hormones on memory consolidation, we reported that corticosterone administration selectively enhances the memory of emotionally arousing experiences because of such critical interactions with training-induced noradrenergic activation within the BLA (Roozendaal et al. 2006). Thus, the present finding that $\mathrm{OFQ} / \mathrm{N}$ and the NOP receptor antagonist interact with noradrenergic activation on memory consolidation suggests that this system may also selectively influence memory for emotionally arousing experiences. Such a role would fit with the broader view that $\mathrm{OFQ} / \mathrm{N}$ is particularly involved in reducing anxiety and stress vulnerability (Jenck et al. 1997; Köster et al.

\section{Learning \& Memory}

www.learnmem.org 
1999; Reinscheid and Civelli 2002). However, it is unlikely that $\mathrm{OFQ} / \mathrm{N}$ in the BLA modulates the memory strength selectively by altering the fearfulness of the memory trace as recent evidence indicates that the BLA is involved in influencing memory of both the aversively motivated aspects of inhibitory avoidance training as well as specific memory of contextual representations of where the footshock was received (Malin and McGaugh 2006).

\section{Materials and Methods}

\section{Subjects}

Male adult Sprague-Dawley rats (280-320 g at time of surgery) from the Charles River Breeding Laboratories were kept individually in a temperature-controlled $\left(22^{\circ} \mathrm{C}\right)$ colony room and maintained on a standard 12-h light/12-h dark cycle (07:00-19:00 h lights on) with ad libitum access to food and water. Training and testing were performed during the light phase of the cycle between 10:00 and 14:00 h. All procedures were performed in compliance with the National Institutes of Health guidelines and were approved by the Institutional Animal Care and Use Committee of the University of California, Irvine.

\section{Surgery}

Animals, adapted to the vivarium for at least $1 \mathrm{wk}$, were anesthetized with sodium pentobarbital $(50 \mathrm{mg} / \mathrm{kg}$ of body weight, i.p.) and given atropine sulfate $(0.4 \mathrm{mg} / \mathrm{kg}$, i.p.) to maintain respiration, and were subsequently injected with $3.0 \mathrm{~mL}$ of saline to facilitate clearance of these drugs and prevent dehydration. The skull was positioned in a stereotaxic frame (Kopf Instruments), and two stainless-steel guide cannulae (15 mm; 23 gauge; Small Parts, Inc.) were implanted bilaterally with the cannula tips $2.0 \mathrm{~mm}$ above the BLA. The coordinates were based on the atlas of Paxinos and Watson (2005): anteroposterior (AP), $-2.8 \mathrm{~mm}$ from bregma; mediolateral (ML), $\pm 5.0 \mathrm{~mm}$ from the midline; dorsoventral (DV), $-6.5 \mathrm{~mm}$ from skull surface; incisor bar $-3.3 \mathrm{~mm}$ from interaural. Other rats received bilateral guide cannulae (15 mm long) with the tips $2.0 \mathrm{~mm}$ above the CEA (coordinates: AP, $-2.2 \mathrm{~mm}$; ML, $\pm 4.3 \mathrm{~mm}$; DV, $-6.0 \mathrm{~mm}$ ). The cannulae were affixed to the skull with two anchoring screws and dental cement. Stylets (15-mm-long 00-insect dissection pins) inserted into each cannula to maintain patency were removed only for the infusion of drugs. After surgery, the rats were retained in an incubator until recovered from anesthesia and were then returned to their home cages. The rats were allowed to recover for a minimum of $7 \mathrm{~d}$ before initiation of training and were handled three times for $1 \mathrm{~min}$ each during this recovery period to accustom them to the infusion procedure.

\section{Inhibitory avoidance apparatus and procedure}

Rats were trained and tested in an inhibitory avoidance apparatus consisting of a trough-shaped alley $(91 \mathrm{~cm}$ long, $15 \mathrm{~cm}$ deep, $20 \mathrm{~cm}$ wide at the top, and $6.4 \mathrm{~cm}$ wide at the bottom) divided into two compartments, separated by a sliding door that opened by retracting into the floor (McGaugh et al. 1988). The starting compartment $(30 \mathrm{~cm})$ was made of opaque white plastic and well lit; the shock compartment $(60 \mathrm{~cm})$ was made of dark, electrifiable metal plates and was not illuminated. Training and testing were conducted in a sound- and light-attenuated room.

For training, the rats were placed in the starting compartment of the apparatus, facing away from the door, and were allowed to enter the dark (shock) compartment. After the rat stepped completely into the dark compartment, the sliding door was closed and a single inescapable footshock was delivered for $1 \mathrm{sec}$. In the first experiment, examining whether OFQ/N impairs memory consolidation, a moderately strong footshock intensity of $0.65 \mathrm{~mA}$ was used. A milder footshock intensity of $0.55 \mathrm{~mA}$ was used in the second experiment examining whether blockade of NOP receptors would enhance memory consolidation. The rats were removed from the shock compartment $15 \mathrm{sec}$ after termination of the footshock and, after drug treatment, returned to their home cages. On the 48-h retention test, as on the training session, the latency to re-enter the shock compartment with all four paws (maximum latency of $600 \mathrm{sec}$ ) was recorded and used as a measure of retention. Longer latencies were interpreted as indicating better retention. Shock was not administered on the retention test trial.

\section{Drug and infusion procedures}

OFQ/N $(0.01,0.1,1,10$, or 100 pmol; synthesized by Research Genetics/Invitrogen) or the peptidergic NOP receptor antagonist [Nphe $\left.{ }^{1}\right]$ nociceptin(1-13) $\mathrm{NH}_{2}$ (1, 10, or 100 pmol; generously provided by Giro Calo, University of Ferrara, Italy) was dissolved in saline and administered into the BLA immediately after inhibitory avoidance training. Other groups of rats received additionally the $\beta_{1}$-adrenoceptor antagonist atenolol (2.0 nmol; Sigma) coadministered with either the $\mathrm{OFQ} / \mathrm{N}$ or NOP receptor antagonist solution. This dose of atenolol was selected on the basis of previous findings indicating that it does not induce memory impairment when administered alone (Roozendaal et al. 2002). To control for time and site specificity, additional groups of rats received intra-BLA infusions of the most effective doses of $\mathrm{OFQ} / \mathrm{N}$ $(1 \mathrm{pmol})$ or $\left[\mathrm{Nphe}^{1}\right]$ nociceptin(1-13) $\mathrm{NH}_{2}(10 \mathrm{pmol}) 3$ or $6 \mathrm{~h}$ after training, or immediate post-training infusions of $\mathrm{OFQ} / \mathrm{N}(1$ pmol) into the CEA. OFQ/N and the NOP receptor antagonist were kept in a stock solution of $1 \mathrm{mM}$ in water at $-80^{\circ} \mathrm{C}$. Bilateral infusions of drug, or an equivalent volume of saline, into the BLA or CEA were made by using a 30-gauge injection needle connected to a $10-\mu \mathrm{L}$ Hamilton microsyringe by polyethylene (PE-20) tubing. The injection needle protruded $2.0 \mathrm{~mm}$ beyond the tip of the cannula and a $0.2-\mu \mathrm{L}$ injection volume per hemisphere was infused over a period of $25 \mathrm{sec}$ by an automated syringe pump (Sage Instruments). The infusion volume was based on findings that this volume of an excitotoxin administered at identical injection sites induces selective lesions of either the BLA or CEA (Roozendaal and McGaugh 1996). Furthermore, drug infusions of this volume into either the BLA or CEA induce differential effects on memory consolidation (Parent and McGaugh 1994; Roozendaal and McGaugh 1997). The injection needles were retained within the cannulae for an additional $20 \mathrm{sec}$ following drug infusion to maximize diffusion and to prevent backflow of drug into the cannulae.

\section{Histology}

Rats were anesthetized with an overdose of sodium pentobarbital $(\approx 100 \mathrm{mg} / \mathrm{kg}$, i.p.; Sigma) and perfused intracardially with $0.9 \%$ $(\mathrm{w} / \mathrm{v})$ saline solution followed by $4 \%(\mathrm{w} / \mathrm{v})$ formaldehyde dissolved in water. Following decapitation, the brains were removed and immersed in fresh $4 \%$ formaldehyde. At least $24 \mathrm{~h}$ before sectioning, the brains were submerged in a $20 \%(\mathrm{w} / \mathrm{v})$ sucrose solution in saline for cryoprotection. Coronal sections of $40 \mu \mathrm{m}$ were cut on a freezing microtome, mounted on gelatin-coated slides, and stained with cresyl violet. The sections were examined under a light microscope, and determination of the location of injection needle tips in the BLA or CEA was made according to the standardized atlas plates of Paxinos and Watson (2005) by an observer blind to drug treatment condition. Rats with injection needle placements outside the BLA or CEA, respectively, or with extensive tissue damage at the injection needle tips, were excluded from analysis.

\section{Statistics}

In the first experiment, training and retention test latencies were analyzed using two-way ANOVAs with immediate post-training infusions of different doses of $\mathrm{OFQ} / \mathrm{N}$ (six levels) and $\beta$-adrenoceptor antagonist (two levels) as between-subject variables. In the second experiment, the between-subject variables for the twoway ANOVAs were NOP receptor antagonist (four levels) and $\beta$-adrenoceptor antagonist (two levels). Further analysis used Fisher's post hoc tests to determine the source of the detected significances. Differences in retention latencies for the delayed infusions or for drug infusions into the CEA were analyzed with 
unpaired $t$-tests (two-tailed). To determine whether learning had occurred, paired $t$-tests were used to compare the training and retention latencies. For all comparisons, a probability level of $<0.05$ was accepted as statistical significance. The number of rats per group is indicated in the figure legends.

\section{Acknowledgments}

We thank Noah Gross, Kimberly Tran, and Brian Kurose for excellent technical assistance and Gabriel Hui for assistance with preparing the figures. Research was supported by NSF grant IOB0618211 (to B.R.) and NIMH grants MH12526 (to J.L.M.) and MH66893 (to R.K.R.).

\section{References}

Bridge, K.E., Wainwright, A., Reilly, K., and Oliver, K.R. 2003. Autoradiographic localization of $\left.{ }^{125} \mathrm{I} \mathrm{Tyr}^{14}\right]$ nociceptin/orphanin FQ binding sites in macaque primate CNS. Neuroscience 118: 513-523.

Brioni, J.D., Nagahara, A.H., and McGaugh, J.L. 1989. Involvement of the amygdala GABAergic system in the modulation of memory storage. Brain Res. 476: 105-112.

Bunzow, J.R., Saez, C., Mortrud, M., Bouvier, C., Williams, J.T., Low, M., and Grandy, D.K. 1994. Molecular cloning and tissue distribution of a putative member of the rat opioid receptor gene family that is not a $\mu, \delta$ or $\kappa$ opioid receptor type. FEBS Lett. 347: 284-288.

Calo, G., Guerrini, R., Rizzi, A., Salvadori, S., and Regoli, D. 2000. Pharmacology of nociceptin and its receptor: A novel therapeutic target. Br. J. Pharmacol. 129: 1261-1283.

Dias, R.D., Carrasco, M.A., Souza, D.O., and Izquierdo, I. 1979. Effect of naloxone, haloperidol and propranolol on cyclic 3',5'-adenosine monophosphate content of rat amygdala. Eur. J. Pharmacol. 60: $345-347$.

Ferry, B., Roozendaal, B., and McGaugh, J.L. 1999. Basolateral amygdala noradrenergic influences on memory storage are mediated by an interaction between $\beta$ - and $\alpha 1$-adrenoceptors. J. Neurosci. 19: $5119-5123$.

Florin, S., Meunier, J., and Costentin, J. 2000. Autoradiographic localization of $\left[{ }^{3} \mathrm{H}\right]$ nociceptin binding sites in the rat brain. Brain Res. 880: $11-16$.

Foord, S.M., Bonner, T.I., Neubig, R.R., Rosser, E.M., Pin, J.P., Davenport, A.P., Spedding, M., and Harmar, A.J. 2005. International Union of Pharmacology XLVI. G protein-coupled receptor list. Pharmacol. Rev. 57: 279-288.

Fukuda, K., Kato, S., Mori, K., Nishi, M., Takeshima, H., Iwabe, N., Miyata, T., Houtani, T., and Sugimoto, T. 1994. cDNA cloning and regional distribution of a novel member of the opioid receptor family. FEBS Lett. 343: 42-46.

Gallagher, M. and Kapp, B.S. 1978. Manipulation of opiate activity in the amygdala alters memory processes. Life Sci. 23: 1973-1977.

Hatfield, T., Spanis, C., and McGaugh, J.L. 1999. Response of amygdala norepinephrine to footshock and GABAergic drugs using in vivo microdialysis and HPLC. Brain Res. 835: 340-345.

Higgins, G.A., Kew, J.N.C., Richards, J.G., Takeshima, H., Jenck, F., Adam, G., Wichmann, J., Kemp, J.A., and Grottick, A.J. 2002. A combined pharmacological and genetic approach to investigate the role of orphanin FQ in learning and memory. Eur. J. Neurosci. 15: $911-922$

Hiramatsu, M. and Inoue, K. 1999. Nociceptin/orphanin FQ and nocistatin on learning and memory impairment induced by scopolamine in mice. Br. J. Pharmacol. 127: 655-660.

Introini-Collison, I.B., Nagahara, A.H., and McGaugh, J.L. 1989. Memory enhancement with intra-amygdala post-training naloxone is blocked by concurrent administration of propranolol. Brain Res. 476: $94-101$

Izquierdo, I. and McGaugh, J.L. 1985. Delayed onset of the amnestic effect of posttraining $\beta$-endorphin: Effects of propranolol administered prior to retention testing. Eur. J. Pharmacol. 113: $105-108$.

Jenck, F., Moreau, J.L., Martin, J.R., Kilpatrick, G.J., Reinscheid, R.K., Monsma Jr., F.J., Nothacker, H.P., and Civelli, O. 1997. Orphanin FQ acts as an anxiolytic to attenuate behavioral responses to stress. Proc. Natl. Acad. Sci. 94: 14854-14858.

Kawahara, Y., Hesselink, M.B., Van Scharrenburg, G., and Westerink, B. 2004. Tonic inhibition by orphanin FQ/nociceptin of noradrenaline neurotransmission in the amygdala. Eur. J. Pharmacol. 485: 197-200.

Köster, A., Montkowski, A., Schulz, S., Stübe, E.M., Knaudt, K., Jenck, F., Moreau, J.L., Nothacker, H.P., Civelli, O., and Reinscheid, R.K. 1999. Targeted disruption of the orphanin FQ/nociceptin gene increases stress susceptibility and impairs stress adaptation in mice. Proc. Natl. Acad. Sci. 96: 10444-10449.
Lachowicz, J.E., Shen, Y., Monsma Jr., F.J., and Sibley, D.R. 1995. Molecular cloning of a novel $G$ protein-coupled receptor related to the opiate receptor family. J. Neurochem. 64: 34-40.

LaLumiere, R.T., Nguyen, L.T., and McGaugh, J.L. 2004. Post-training intrabasolateral amygdala infusions of dopamine modulate consolidation of inhibitory avoidance memory: Involvement of noradrenergic and cholinergic systems. Eur. J. Neurosci. 20: 28042810.

Liang, J.C., Juler, R.G., and McGaugh, J.L. 1986. Modulating effects of posttraining epinephrine on memory: Involvement of the amygdala noradrenergic system. Brain Res. 368: 125-133.

Liang, K.C., Chen, L.L., and Huang, T.E. 1995. The role of amygdala norepinephrine in memory formation: Involvement of memory enhancing effects of peripheral epinephrine. Chin. J. Physiol. 38: 81-91.

Ma, S., Roozendaal, B., Burazin, T.C.D., Tregear, G.W., McGaugh, J.L., and Gundlach, A.L. 2005. Relaxin receptor activation in the basolateral amygdala impairs memory consolidation. Eur. J. Neurosci. 22: 2117-2122.

Malin, E.L. and McGaugh, J.L. 2006. Differential involvement of the hippocampus, anterior cingulate cortex, and basolateral amygdala in memory for context and footshock. Proc. Natl. Acad. Sci. 103: 19591963.

Mamiya, T., Yamada, K., Miyamoto, Y., König, N., Watanabe, Y., Noda, Y., and Nabeshima, T. 2003. Neuronal mechanism of nociceptin-induced modulation of learning and memory: Involvement of N-methyl-D-aspartate receptors. Mol. Psychiatry 8: $752-765$.

Manabe, T., Noda, Y., Mamiya, T., Katagiri, H., Houtani, T., Nishi, M., Noda, T., Takahashi, T., Sugimoto, T., Nabeshima, T., et al. 1998. Facilitation of long-term potentiation in mice lacking nociceptin receptors. Nature 394: 577-581.

McGaugh, J.L. 2000. Memory: A century of consolidation. Science 287: 248-251

McGaugh, J.L. 2004. The amygdala modulates the consolidation of memories of emotionally arousing experiences. Annu. Rev. Neurosci. 27: 1-28.

McGaugh, J.L., Introini-Collison, I.B., and Nagahara, A. 1988. Memory-enhancing effects of post-training naloxone: Involvement of $\beta$-adrenergic influences in the amygdaloid complex. Brain Res. 446: $37-49$.

McGaugh, J.L., Cahill, L., and Roozendaal, B. 1996. Involvement of the amygdala in memory storage: Interaction with other brain systems. Proc. Natl. Acad. Sci. 93: 13508-13514.

McIntyre, C.K., Power, A.E., Roozendaal, B., and McGaugh, J.L. 2003 Role of the basolateral amygdala in memory consolidation. Ann. N.Y. Acad. Sci. 985: 273-293.

McIntyre, C.K., Roozendaal, B., and McGaugh, J.L. 2004. Glucocorticoid treatment enhances training-induced norepinephrine release in the amygdala. Abstract Viewer/Itinerary Planner, Program No. 772.12. Society for Neuroscience, Washington, D.C.

Meis, S. and Pape, H.-C. 1998. Postsynaptic mechanisms underlying responsiveness of amygdaloid neurons to nociceptin/orphanin FQ. J. Neurosci. 18: 8133-8144.

Meis, S. and Pape, H.-C. 2001. Control of glutamate and GABA release by nociceptin/orphanin FQ in the rat lateral amygdala. J. Physiol. 532: 701-712.

Meunier, J.C., Mollereau, C., Toll, L., Suaudeau, C., Moisand, C., Alvinerie, P., Butour, J.L., Guillemot, J.C., Ferrara, P., Monserrat, B. et al. 1995. Isolation and structure of the endogenous agonist of opioid receptor-like ORL1 receptor. Nature 377: 532-535.

Mogil, J.S. and Pasternak, G.W. 2001. The molecular and behavioral pharmacology of the orphanin $\mathrm{FQ} /$ nociceptin peptide and receptor family. Pharmacol. Rev. 53: 381-415.

Neal Jr., C.R., Mansour, A., Reinscheid, R.K., Nothacker, H.P., Civelli, O., Akil, H., and Watson Jr., S.J. 1999a. Opioid receptor-like (ORL1) receptor distribution in the rat central nervous system: Comparison of ORL1 receptor mRNA expression with ${ }^{125} \mathrm{I}-\left[{ }^{14} \mathrm{Tyr}\right]$-orphanin FQ binding. J. Comp. Neurol. 412: 563-605.

Neal Jr., C.R., Mansour, A., Reinscheid, R.K., Nothacker, H.P., Civelli, O., and Watson Jr., S.J. 1999b. Localization of orphanin FQ (nociceptin) peptide and messenger RNA in the central nervous system of the rat. J. Comp. Neurol. 406: 503-547.

Noda, Y., Mamiya, T., Manabe, T., Nishi, M., Takeshima, H., and Nabeshima, T. 2000. Role of nociceptin systems in learning and memory. Peptides 21: 1063-1069.

Parent, M.B. and McGaugh, J.L. 1994. Post-training infusion of lidocaine into the amygdala basolateral complex impairs retention of inhibitory avoidance training. Brain Res. 661: 97-103.

Paxinos, G. and Watson, C. 2005. The rat brain in stereotaxic coordinates, 5 th ed. Academic Press, San Diego.

Pelletier, J.G., Likhtik, E., Filali, M., and Paré, D. 2005. Lasting increases

\section{Learning \& Memory}


in basolateral amygdala activity after emotional arousal: Implications for facilitated consolidation of emotional memories. Learn. Mem. 12: $96-102$.

Perkins, J.P. and Moore, M.M. 1973. Characterization of the adrenergic receptors mediating a rise in cyclic $3^{\prime}, 5^{\prime}$-adenosine monophosphate in rat cerebral cortex. J. Pharmacol. Exp. Ther. 185: 371-378.

Quirarte, G.L., Galvez, R., Roozendaal, B., and McGaugh, J.L. 1998. Norepinephrine release in the amygdala in response to footshock and opioid peptidergic drugs. Brain Res. 808: 134-140.

Redrobe, J.P., Calo, G., Guerrini, R., Regoli, D., and Quirion, R. 2000. [Nphe ${ }^{1}$-Nociceptin (1-13)- $\mathrm{NH}_{2}$, a nociceptin receptor antagonist, reverses nociceptin-induced spatial memory impairments in the Morris water maze task in rats. Br. J. Pharmacol. 131: 1379-1384.

Reinscheid, R.K. and Civelli, O. 2002. The orphanin FQ/nociceptin knockout mouse: A behavioral model for stress responses. Neuropeptides 36: 72-76.

Reinscheid, R.K., Nothacker, H.P., Bourson, A., Ardati, A., Henningsen, R.A., Bunzow, J.R., Grandy, D.K., Langen, H., Monsma Jr., F.J., and Civelli, O. 1995. Orphanin FQ: A neuropeptide that activates an opioidlike G protein-coupled receptor. Science 270: 792-794.

Roozendaal, B. and McGaugh, J.L. 1996. Amygdaloid nuclei lesions differentially affect glucocorticoid-induced memory enhancement in an inhibitory avoidance task. Neurobiol. Learn. Mem. 65: 1-8.

Roozendaal, B. and McGaugh, J.L. 1997. Glucocorticoid receptor agonist and antagonist infused into the basolateral but not central amygdala modulates memory storage. Neurobiol. Learn. Mem. 67: 176-179.

Roozendaal, B., Quirarte, G.L., and McGaugh, J.L. 2002. Glucocorticoids interact with the basolateral amygdala $\beta$-adrenoceptor-cAMP/PKA system in influencing memory consolidation. Eur. J. Neurosci. 15: $553-560$.

Roozendaal, B., Okuda, S., Van der Zee, E.A., and McGaugh, J.L. 2006. Glucocorticoid enhancement of memory requires arousal-induced noradrenergic activation in the basolateral amygdala. Proc. Natl. Acad. Sci. 103: 6741-6746.

Sandin, J., Georgieva, J., Schott, P.A., Ögren, S.O., and Terenius, L. 1997. Nociceptin/orphanin FQ microinjected into hippocampus impairs spatial learning in rats. Eur. J. Neurosci. 9: 194-197.

Sandin, J., Ögren, S.O., and Terenius, L. 2004. Nociceptin/orphanin FQ modulates spatial learning via ORL-1 receptors in the dorsal hippocampus of the rat. Brain Res. 997: 222-233.

Tomaz, C., Dickinson-Anson, H., and McGaugh, J.L. 1992. Basolateral amygdala lesions block diazepam-induced anterograde amnesia in an inhibitory avoidance task. Proc. Natl. Acad. Sci. 89: 3615-3619.

Tomaz, C., Dickinson-Anson, H., McGaugh, J.L., Souza-Silva, M.A., Viana, M.B., and Graeff, F.G. 1993. Localization in the amygdala of the amnestic action of diazepam on emotional memory. Behav. Brain Res. 58: 99-105.

Williams, C.L., Men, D., Clayton, E.C., and Gold, P.E. 1998. Norepinephrine release in the amygdala following systemic injection of epinephrine or escapable foot shock: Contribution of the nucleus of the solitary tract. Behav. Neurosci. 112: 1414-1422.

Received August 11, 2006; accepted in revised form October 31, 2006. 


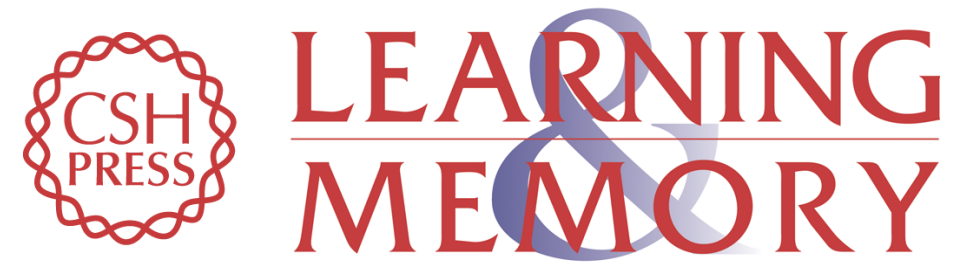

\section{Orphanin FQ/nociceptin interacts with the basolateral amygdala noradrenergic system in memory consolidation}

Benno Roozendaal, Ray Lengvilas, James L. McGaugh, et al.

Learn. Mem. 2007, 14: originally published online January 3, 2007

Access the most recent version at doi:10.1101//m.403607

References This article cites 54 articles, 14 of which can be accessed free at:

http://learnmem.cshlp.org/content/14/1-2/29.full.html\#ref-list-1

License

Email Alerting Receive free email alerts when new articles cite this article - sign up in the box at the Service top right corner of the article or click here. 